\title{
Analisis Karakter Penting dan Skrining Marka-marka SSR yang Berasosiasi dengan Gen Ketahanan terhadap Wereng Coklat pada Lima Kultivar Padi
}

\section{Important Character Analysis and Screening of SSR Marker Associated with the Brown Resistance Plant in Five Rice Cultivars}

\author{
Gigih Ibnu Prayoga ${ }^{1}$, Danar Dono ${ }^{2}$, Neni Rostini ${ }^{2}$, dan Nono Carsono ${ }^{2}$ \\ ${ }^{2}$ Staf Pengajar Fakultas Pertanian Universitas Bangka Belitung \\ ${ }^{2}$ Staf Pengajar Fakultas Pertanian Universitas Padjadjaran
}

\begin{abstract}
Brown planthopper (Nilaparvata lugens Stal) is well-known as the major pest in rice cultivation in Indonesia and other countries in Asia. Developing resistant rice lines is the ideal option for economic and effective management. The experiments were aimed to obtain the important traits between Brown planthopper (BPH) resistant and susceptible genotypes, to obtain SSR markers that can be used in Marker Assisted Selection (MAS) and association of SSR markers with important traits. In this study, characterization of important traits and screening of eight SSR markers were performed for five genotypes i.e. PTB-33 (resistant genotype), IR-64 (tolerant), Pandan Wangi (susceptible), Ciherang (susceptible), and Sintanur (susceptible). PTB-33 showed higher photosynthetic rate (tolerant ability), longer trichomes size (antixenosis ability), and lower protein content (antibiosis ability) compared with other cultivars. RM8213 exhibited visible polymorphic bands between PTB-33 and other cultivars, meanwhile RM586 and RM589 showed polymorphic bands between PTB-33 and other cultivars, except with cv. IR-64. Z-mantel test for correlation between physiological traits and SSR markers showed that Obph4 and Bph17(t) genes highly correlated with photosynthetic rates and trichomes length, whereas Bph3 and bph4 genes showed a high level of correlation with protein content.
\end{abstract}

Keywords : brown planthopper, important traits, marker, bph gene, visualization

\begin{abstract}
Abstrak : Hama wereng cokelat telah lama menjadi masalah utama dalam budidaya padi di Indonesia dan beberapa negara Asia lainnya. Merakit tanaman yang memiliki ketahanan terhadap hama ini, dipandang sebagai pendekatan yang lebih efektif dan ramah terhadap lingkungan dan manusia. Penelitian ini bertujuan untuk memperoleh perbedaan pada karakter penting padi antara kaultivar padi tahan dengan kultivar rentan wereng cokelat, selain itu juga untuk mendapatkan marka-marka SSR yang bisa digunakan untuk Marker Assisted Selection (MAS) dan hubungannya dengan karakter penting. Penelitian ini meliputi upaya pengamatan karakter penting dan skrining delapan marka SSR yang diduga berkaitan dengan gen bph (ketahanan terhadap wereng coklat) pada lima kultivar padi tetua yaitu PTB-33 (genotipe tahan), IR-64, Pandan Wangi, Ciherang, dan Sintanur (kultivar lokal). Pengujian karakter penting pada kultivar PTB-33 memiliki laju fotosintesis yang lebih tinggi (toleran), trikoma yang lebih panjang (antixenosis), dan kandungan protein yang lebih rendah (antibiosis) dibandingkan kultivar lainnya yang diuji. Hasil visualisasi pada delapan marka yang memperlihatkan bahwa RM8213 menunjukkan adanya polimorphisme pita DNA pada genotipe tahan PTB-33 dengan kultivar lainnya. Selain itu, marka RM586 dan RM589 juga menunjukkan adanya polimorphisme pada kultivar PTB-33 dengan kultivar lainnya kecuali dengan kultivar IR-64. Hasil analisis Z-Mantel antara marka SSR dengan karakter karakter penting tetua menunjukkan bahwa gen $Q b p h 4$ dan $B p h 17(\mathrm{t})$ mempunyai korelasi yang sangat tinggi dengan karakter laju fotosintesis dan panjang trikoma, sedangkan gen gen Bphs dan $b p h 4$ berkorelasi tinggi dengan kandungan protein.
\end{abstract}

Kata kunci : gen $b p h$, karakter penting, marka, visualisasi, wereng cokelat.

\section{Pendahuluan}

Produktivitas padi di Indonesia saat ini masih relatif rendah $\left(3,5-5,2\right.$ ton.ha $\left.{ }^{-1}\right)$ yang dikarenakan oleh berbagai sebab, diantaranya terkait dengan faktor pembatas pertumbuhan dan perkembangan tanaman, yaitu adanya serangan hama dan penyakit. Hama wereng cokelat (Nilaparvata lugens Stal) 
merupakan hama utama padi pada pertanaman padi hampir di semua negara. Selain itu, hama wereng juga merupakan vektor bagi virus-virus utama padi seperti virus tungro dan virus kerdil (Nagadhara et al., 2004). Serangan hama dan virus ini mampu menurunkan produktivitas hasil padi, bahkan dapat menyebabkan pertanaman padi menjadi tidak menghasilkan sama sekali (puso).

Upaya pencegahan yang dapat dilakukan adalah melalui perakitan tanaman padi yang tahan beragam biotipe wereng cokelat. Upaya ini dapat dipandang lebih ekonomis dan ramah lingkungan karena dapat menghindari penggunaan insektisida yang berlebihan (Maqbool et al. 2001). Upaya perakitan kultivar padi tahan wereng cokelat dapat dilakukan dengan berbagai metode, salah satunya yaitu metode introgresi atau penggabungan gen-gen ke dalam satu kultivar melalui persilangan.

Langkah awal pelaksanaan teknik introgresi adalah pemilihan tetua persilangan. Sebagai tetua donor, kultivar yang dipilih harus memiliki ketahanan terhadap wereng cokelat. Berdasarkan studi literatur, diketahui bahwa genotipe PTB-33 merupakan salah satu kultivar tahan wereng cokelat dengan beberapa gen tahan wereng cokelat (Bph or bph; Jairin et al., 2007a; Sun et al., 2005; Nugaliyadde et al., 2004; Santhanalakhsmi et al., 2010). PTB-33 merupakan kultivar introduksi dari India yang memiliki gen ketahanan terhadap wereng cokelat, yaitu $b p h 2, B p h 3$, bph4 yang terdapat pada kromosom 6 , serta beberapa gen ketahanan lainnya yang diduga merupakan QTL (quantitative trait loci; Santhanalakshmi et al., 2010). Gen-gen bph inilah yang direncanakan untuk diintrogresikan ke dalam padi kultivar unggul Indonesia (IR-64, Pandan Wangi, Ciherang, dan Sintanur) sehingga akan diperoleh galur-galur padi harapan yang memiliki ketahanan terhadap wereng cokelat. Kultivarkultivar unggul Indonesia tersebut dipilih karena memiliki hasil dan kualitas beras yang tinggi, namun rentan terhadap wereng cokelat.

Langkah selanjutnya setelah persilangan adalah penerapan Marker Assisted Selection (MAS) dengan marka-marka SSR (Simple Sequence Repeats) yang merupakan marka yang sangat polimorfik, berbasis PCR sehingga mudah diterapkan. MAS merupakan upaya untuk menseleksi tanaman yang diinginkan dengan memanfaatkan teknologi marka molekuler. Jena et al.,(2009) telah berhasil mengaplikasikan teknik MAS untuk merakit padi Japonica yang tahan wereng cokelat, salah satunya dengan aplikasi SSR. Penggunaan metode SSR untuk aplikasi MAS telah berhasil diaplikasikan pada tanaman padi untuk berbagai tujuan termasuk perakitan kultivar padi tahan hama (Sharma et al., 2004; Jena et al., 2006; Li et al., 2006; Sun et al., 2006; Jena et al., 2009). Penggunaan MAS sangat bermanfaat untuk membantu proses seleksi galur-galur yang sedang bersegregasi dan memiliki gen-gen yang diharapkan.

Salah satu syarat keberhasilan MAS dengan metode SSR adalah tersedianya marka-marka spesifik yang mampu mendeteksi gen terkait. Berdasarkan hal itu, dalam penelitian ini akan digunakan beberapa primer SSR, yaitu RM589 dan RM586 yang terpaut dengan gen Bph3 dan bph4 (Jena and Mackill, 2008; Jairin et al., 2007b), RM8213 dan RM5953 yang terpaut dengan gen $B p h 17(\mathrm{t})$ (Sun et al., 2005), serta beberapa marka lainnya (RM7, RM8072, dan RM19291) yang diketahui dapat mendeteksi keberadaan gen $b p h$. RM589 dan RM586 telah terbukti berhasil mendeteksi gen $b p h$ pada kultivar PTB-33, namun marka-marka lainnya belum pernah digunakan untuk mendeteksi gen $b p h$ pada kultivar PTB-33 dan kultivar lokal yang digunakan pada penelitian ini. Marka-marka ini nantinya akan diuji (diskrining) untuk mengetahui kehandalannya dalam membedakan kultivar tahan dan rentan. Marka yang lolos seleksi akan digunakan untuk aplikasi MAS pada generasi keturunan.

Upaya lain yang harus dilakukan selain upaya introgresi dan aplikasi MAS dalam rangka memperoleh kultivar tahan wereng cokelat yang durable yaitu mengetahui karakter penting yang dimiliki oleh kultivar tahan. Karakter penting tanaman mempunyai peranan penting terhadap kemampuan tanaman untuk bertahan dari serangan wereng (Manuwoto dan Adijuwana, 1991; Wang et al, 2008; Chen, 2009; Horgan, 2009). Lebih lanjut Horgan (2009) mengemukakan bahwa pendekatan baru dalam pengembangan kultivar resistan yang durable didasarkan pada strategi untuk menggabungkan gen (pyramiding), dimana strategi ini bergantung kepada pengetahuan mengenai fungsi gen yang berhubungan dengan sistem ketahanan. Informasi mengenai karakter penting tanaman seperti kandungan protein serta hubungannya dengan keberadaan gen $b p h$ hasil aplikasi MAS pada kultivar tahan, nantinya dapat digunakan untuk mengembangkan galur-galur padi harapan yang memiliki tingkat ketahanan yang tinggi, broad spectrum terhadap biotipe wereng cokelat (Brar et al., 2009) dan diharapkan memiliki ketahanan yang bersifat durable.

Berdasarkan pemaparan-pemaparan diatas, penggunaan teknik introgresi yang digabungkan dengan aplikasi MAS merupakan cara yang efektif untuk merakit kultivar padi tahan wereng cokelat. Hasil akhir yang diharapkan dari penelitian ini yaitu 
diperolehnya marka-marka SSR yang terbukti dapat menseleksi kultivar tahan dan rentan berdasarkan ukuran pita DNA sehingga bisa digunakan untuk aplikasi MAS. Selain itu, diharapkan diperoleh informasi mengenai perbedaan karakter penting antara kultivar tahan dan rentan serta korelasinya dengan marka-marka SSR yang digunakan, sehingga dapat digunakan sebagai dasar perakitan dan seleksi berdasarkan karakter tanaman.

\section{Bahan dan Metode}

Kegiatan penanaman kultivar padi dilaksanakan di rumah kaca, kebun percobaan Fakultas Pertanian Unpad. Kegiatan skrining marka dilakukan di Laboratorium Analisis Tanaman Faperta Unpad. Percobaan analisis karakter penting dilaksanakan di rumah kaca dan Laboratorium Analisis Tanaman Faperta Unpad.

Bahan tanaman yang digunakan adalah kultivar padi tahan wereng cokelat yaitu PTB-33 sebagai tetua donor, sedangkan untuk tetua betina digunakan kultivar padi lokal yaitu IR-64, Ciherang, Pandan Wangi, dan Sintanur.

\section{Marker Screening}

Peralatan yang digunakan untuk kegiatan percobaan molekuler yaitu sarung tangan, alumunium foil, PCR (mastercycler Epgradient dari Eppendorf), spectrophotometer (Rayleigh UV-9200), tangki elektroforesis, gel documentation system (G-Box dari Syngene), grindler dan prestle, refrigerated microsentrifuge (Eppendorf), pipet dan pipet tip beragam ukuran, lemari pendingin $-20^{\circ} \mathrm{C}$, inkubator, ice maker dan water bath. Bahan yang digunakan dalam percobaan molekuler adalah ethanol, isopropanol, fenol, chloroform, CTAB, PCR kit (Go taq green master mix dari Promega), primer SSR, aquades, TE buffer, dan miliQ.

Seleksi marka dilakukan secara molekuler dengan marka SSR (Single Sequence Repeat) berbasis PCR (polymerase chain reaction). Marka-marka yang ditelusuri melalui literatur, selanjutnya diuji untuk mendeteksi gen bph pada kultivar PTB-33. Marka yang terbukti mampu mendeteksi gen bph akan digunakan untuk menseleksi tanaman hasil persilangan. Daftar marka-marka yang diuji beserta gen $b p h$ yang terkait pada penelitian ini dapat dilihat pada Tabel 1. Tahapan pengerjaan seleksi marka secara berurutan yaitu isolasi DNA, dilanjutkan dengan pengujian konsentrasi dan kualitas DNA, amplifikasi DNA dengan PCR, elektroforesis DNA, dan visualisasi DNA.

Template DNA yang akan diamplifikasi, telah diseragamkan konsentrasinya menjadi 20ng/ $\mu \mathrm{l}$ berdasarkan hasil penghitungan dengan spectrophotometer. Amplifikasi pada PCR akan dilakukan dengan menggunakan kondisi amplifikasi optimum dengan mesin PCR Thermocycler (Eppendorf). Kondisi optimum diperoleh setelah dilakukan berbagai amplifikasi pada suhu dan waktu yang berbeda-beda. Sebagai standar pengerjaan, amplifikasi fragmen dilakukan dengan mengikuti metode Kumari et al., (2010), yaitu :

- satu siklus $94^{\circ} \mathrm{C}$ selama 5 menit untuk denaturasi awal (pemisahan double helix DNA),

- 36 siklus: $94^{\circ} \mathrm{C}$ selama 1 menit untuk denaturasi, $55^{\circ} \mathrm{C}$ selama 1 menit untuk hibridisasi primerDNA (annealing), dan $72^{\circ} \mathrm{C}$ selama 1 menit untuk pemanjangan (elongation),

- diikuti oleh satu siklus $72{ }^{\circ} \mathrm{C}$ selama 7 menit untuk elongation akhir.

Tabel 1. Marka-marka SSR yang digunakan untuk skrining marka dan gen $b p h$ yang terkait.

\begin{tabular}{|c|c|c|c|c|c|c|c|}
\hline \multirow[b]{2}{*}{ No } & \multirow[b]{2}{*}{ Marka } & \multirow[b]{2}{*}{ Gen terkait } & \multirow{2}{*}{$\begin{array}{l}\text { Kromo- } \\
\text { som }\end{array}$} & \multicolumn{2}{|l|}{$\underline{\text { Sekuens Primer }}$} & \multirow{2}{*}{$\begin{array}{l}\text { PCR } \\
\text { product } \\
\text { size }\end{array}$} & \multirow[b]{2}{*}{ Sumber } \\
\hline & & & & Forward & Reverse & & \\
\hline 1. & $\mathrm{RM} 7$ & Qbph 3 & 3 & ttcgecatgaagtctctcg & cctcccatcatttcgttgtt & $180 \mathrm{bp}$ & Sun et al., 2005 \\
\hline 2. & RM313 & Qbph 3 & 3 & tgctacaagtgttcttcaggac & gctcaccttttgtgttccac & $111 \mathrm{bp}$ & Sun et al., 2005 \\
\hline 3. & $\mathrm{RM} 8072$ & Bph 3 & 6 & gatcactcaggtcatccattc & aatcagagaggctaaagacaataat & 146bp & Jairin et al., $2007 \mathrm{a}$ \\
\hline 4. & RM19291 & Bph 3 & 6 & cacttgcacgtgtcctctgtacg & gtgtttcagttcaccttgcatcg & $146 \mathrm{bp}$ & Jairin et al., 2007a \\
\hline 5. & RM586 & Bph 3 dan bph 4 & $6 \mathrm{~S}$ dan 6 & acctcgcgttattaggtaccc & gagatacgccaacgagatacc & $271 \mathrm{bp}$ & Jairin et al.,, 2007a \\
\hline 6. & RM589 & Bph 3 dan bph 4 & $6 \mathrm{~S}$ dan 6 & atcatggtcggtggcttaac & caggttccaaccagacactg & $186 \mathrm{bp}$ & Jairin et al., 2007a \\
\hline 7. & RM5953 & $Q b p h 4$ dan $B p h 17(\mathrm{t})$ & 4 dan $4 \mathrm{~S}$ & aaactttctgtgatggtatc & atccttgtctagaattgaca & $129 \mathrm{bp}$ & Sun et al., 2005 \\
\hline 8. & $\mathrm{RM} 8213$ & $Q b p h 4$ dan $B p h 17(\mathrm{t})$ & 4 dan $4 \mathrm{~S}$ & agcccagtgatacaaagatg & gcgaggagataccaagaaag & $177 \mathrm{bp}$ & Sun et al., 2005 \\
\hline
\end{tabular}


Produk hasil amplifikasi selanjutnya dielektroforesis dengan menggunakan agarose gel (1,5-3 \%) pada larutan 0,5X TBE yang di-running pada tegangan listrik tertentu selama waktu yang ditentukan. Dalam pengerjaannya, akan dilakukan optimasi kondisi elektroforesis meliputi konsentrasi agarose gel, tegangan listrik dan waktu elektroforesis. Sebagai standar pengerjaan, elektroforesis akan dilakukan berdasarkan metode Kumari et al. (2010), yaitu 3\% agarose gel direndam pada larutan $0,5 \mathrm{X}$ TBE buffer dan dialiri tegangan listrik 75 volt selama 90 menit. Marka yang terbukti mampu menunjukkan polimorfisme band atau fragmen atau gen yang diinginkan sesuai literature, selanjutnya digunakan untuk menyeleksi tanaman pada galur keturunan.

\section{Analisis Karakter penting}

Pengujian analisis karakter karakter penting dilakukan dengan menggunakan pot plastik, gunting, alat tulis, lemari pendingin $-20^{\circ} \mathrm{C}$, kamera, sarung tangan, tisue, spidol permanen, kertas parafin, petridis, kertas label, portable photosyntetic meter, portable leaf area meter, porometer, spectrophotometer (Rayleigh UV-9200), chlorophyl content meter, dan meteran. Peralatan yang digunakan pada kegiatan penanaman padi yaitu ember plastik, baki persemaian, dan emrat. Bahan yang digunakan untuk pengujian karakter karakter penting adalah ethanol, Tris $\mathrm{HCl}$, EDTA, TE buffer, $\beta$-Mecaptoethanol, coomasie brilian blue (CBB), dan bovine serum albumin (BSA).

Persiapan tanaman padi untuk analisis karakter karakter penting tetua dilakukan berdasarkan metode Wang et al. (2008) yang telah dimodifikasi. Penanaman disusun berdasarkan Rancangan Acak Kelompok (RAK). Lima kultivar padi dari setiap genotip dikecambahkan dan disemai pada pot-pot terpisah. Tiap pot ditanam sebanyak 15 tanaman muda dan ditumbuhkan di rumah kaca dan diulang sebanyak 5 kali. Saat tanaman berumur 30 hst, dilakukan pengamatan karakter karakter penting pada 10 tanaman di setiap ulangan yang dipilih secara acak. Setelah pengamatan, 10 tanaman tersebut kemudian dipanen dan selanjutnya digunakan untuk analisis kandungan protein.

Pengamatan karakter pertumbuhan meliputi pengukuran luas daun dan panjang trikoma. Pengamatan karakter fotosintesis meliputi bukaan stomata, kandungan klorofil, dan laju fotosintesis. Pengukuran bukaan stomata diukur dengan menggunakan alat Porometer, pengukuran kandungan klorofil dilakukan dengan menggunakan alat Chlorophyl Content Meter, pengukuran laju fotosintesis diukur menggunakan Portable
Photosyntetic Meter, dan pengukuran panjang trikoma menggunakan mikroskop. Pengujian kandungan protein akan dilaksanakan mengikuti metode Bradford (1976) cit Wang et al., (2008).

\section{Analisis Data}

Data hasil pengamatan karakter karakter penting yang diperoleh diuji terlebih dahulu menggunakan uji normalitas sehingga nantinya dapat ditentukan perlu tidaknya dilakukan transformasi data. Pengujian normalitas data dilakukan dianalisis melalui uji KolmogorovSmirnov. Data yang telah diuji normalitas selanjutnya dianalisis varian (ANOVA). ANOVA dilakukan berdasarkan rancangan percobaan yang dilakukan, yaitu Rancangan Acak Kelompok (RAK). Selanjutnya nilai rata-rata perlakuan yang berbeda nyata berdasarkan hasil ANOVA dihitung dengan Uji Jarak Berganda Duncan (Duncan Multiple Range Test) pada taraf nyata 5\%. Data karakter penting dan data marka molekuler yang diperoleh kemudian dianalisis korelasinya menggunakan analisis ZMantel. Data diolah dengan menggunakan software SPSS v.17.0 dan DSAASTAT v.1.021.

\section{Hasil dan Pembahasan}

\section{Karakter Penting Tanaman}

Data pada Tabel 2 menunjukkan bahwa tidak terdapat perbedaan antara kultivar tahan PTB-33 dengan kultivar lainnya untuk karakter luas daun, kandungan klorofil, dan konduktan stomata. Hal ini menunjukkan bahwa ketahanan pada kultivar PTB33 tidak berhubungan dengan ketiga karakter tersebut. Selain itu, tidak adanya perbedaan yang nyata antar kultivar lokal yang tidak resisten terhadap wereng cokelat, menunjukkan bahwa ketiga karakter tersebut tidak ada kaitannya dengan karakter ketahanan terhadap wereng cokelat. Akan tetapi, penelitian yang telah dilakukan Wang et al. (2008) memperlihatkan bahwa karakter luas daun, kandungan klorofil, dan konduktan stomata padi mengalami perubahan ketika diinfestasi oleh wereng cokelat. Pada kultivar rentan yang diuji, ketiga karakter tersebut mengalami penurunan saat diinfestasi, kecuali pada kultivar tahan. Namun, pada penelitian ini tidak dilakukan pengujian langsung menggunakan wereng cokelat (bioassay), sehingga diduga bahwa ketiga karakter tersebut selain karakter yang menunjukkan respon sebagai akibat dari serangan wereng dan diduga berkaitan dengan mekanisme ketahanan yang aktif, yaitu mekanisme ketahanan yang ditunjukkan tanaman sebagai respon pertahanan ketika terjadi serangan oleh wereng cokelat. 
Tabel 2. Hasil analisis karakter penting dengan menggunakan uji Jarak Berganda Duncan.

\begin{tabular}{lccccc}
\hline Kultivar & $\begin{array}{c}\text { Luas } \\
\text { Daun }\end{array}$ & $\begin{array}{c}\text { Kandu- } \\
\text { ngan }\end{array}$ & $\begin{array}{c}\text { Konduk- } \\
\text { tan }\end{array}$ & $\begin{array}{c}\text { Fotosin- } \\
\text { tesis }\end{array}$ & $\begin{array}{c}\text { Panjang } \\
\text { Trikoma } \\
\end{array}$ \\
& $\left(\mathbf{c m}^{2}\right)$ & $\begin{array}{c}\text { Klorofil } \\
(\mathbf{C C I})\end{array}$ & $\begin{array}{c}\text { Stomata } \\
(\mathbf{s} / \mathbf{m})\end{array}$ & $\mathbf{s})$ & \\
\hline PTB-33 & $1,66 \mathrm{~m} \mathbf{m}^{2}$ & $(\mathbf{m m})$ \\
IR-64 & 2,06 a & $2,06 \mathrm{a}$ & $406,32 \mathrm{a}$ & $7,28 \mathrm{a}$ & $0,82 \mathrm{a}$ \\
Pandan & $2,25 \mathrm{a}$ & $2,03 \mathrm{a}$ & $434,32 \mathrm{a}$ & $7,41 \mathrm{a}$ & $0,17 \mathrm{bc}$ \\
Wangi & $2,23 \mathrm{a}$ & $1,97 \mathrm{a}$ & $496,40 \mathrm{a}$ & $5,83 \mathrm{~b}$ & $0,12 \mathrm{c}$ \\
Ciherang & $1,82 \mathrm{a}$ & $1,88 \mathrm{a}$ & $375,80 \mathrm{a}$ & $7,48 \mathrm{a}$ & $0,18 \mathrm{~b}$ \\
Sintanur & & & & & \\
\hline
\end{tabular}

Keterangan : nilai rata-rata yang memiliki huruf yang sama pada kolom yang sama menunjukkan tidak berbeda nyata menurut uji Jarak Berganda Duncan pada taraf 5\%.

Hasil pengujian pada karakter karakter laju fotosintesis menunjukkan bahwa kultivar PTB-33 memiliki laju fotosintesis yang lebih tinggi, namun tidak berbeda nyata jika dibandingkan dengan kultivar IR-64, Pandan Wangi, dan Sintanur (Tabel 2). Laju fotosintesis yang tinggi selain berpengaruh terhadap hasil tanaman, juga dapat menjadi pertahanan tanaman terhadap serangan hama (Johnson et al., 1983). Wang et al., (2008) juga menjelaskan bahwa kultivar tahan mempunyai kemampuan untuk mengembalikan aktivitas fotosintesis seperti semula dan tumbuh normal jika terjadi serangan wereng cokelat. Hal ini dapat terjadi jika tanaman mempunyai laju fotosintesis yang tinggi, sehingga aliran hasil fotosintesis dari source menuju sink tidak terganggu ataupun menurun dan tanaman tetap tumbuh normal. Laju fotosintesis yang tinggi pada kultivar PTB-33 dapat menjadi salah satu faktor pendukung ketahanan kultivar ini terhadap wereng cokelat.

Perbedaan yang signifikan antara kultivar tahan PTB-33 dibandingkan empat kultivar lainnya yang diuji hanya ditunjukkan oleh karakter panjang trikoma (Tabel 2). Pada karakter panjang trikoma, hasil yang diperoleh menunjukkan bahwa kultivar PTB-33 memiliki rata-rata panjang trikoma 0,82 $\mathrm{mm}$, jauh melebihi kultivar lainnya yang memiliki rata-rata $0,12-0,18 \mathrm{~mm}$. Chandramani et al., (2009) dan Indiati, (2004) menyatakan bahwa ketahanan suatu kultivar terhadap serangan hama juga dipengaruhi oleh faktor biofisik tanaman seperti panjang dan kerapatan trikoma. Penelitian yang telah dilakukan Junengsih, dkk (2012, tidak dipubikasikan) sebelumnya menunjukkan bahwa kultivar PTB-33 memiliki trikoma yang lebih rapat dibandingkan kultivar IR-64 dan Ciherang. Pada penelitian ini juga diperoleh hasil bahwa kultivar PTB-33 memiliki trikoma yang lebih panjang dibandingkan kultivar lainnya (Tabel 2). Adanya trikoma yang panjang dan rapat ini dapat menjadi salah satu faktor ketahanan kultivar PTB-33, karena karakter trikoma yang panjang dan rapat dapat menghambat kebiasaan makan dan kemampuan wereng cokelat menyentuh permukaan daun untuk meletakan telur.

Beberapa penelitian yang telah dilakukan sebelumnya menyebutkan bahwa kultivar PTB-33 memiliki mekanisme ketahanan berupa antibiosis (Baehaki dan Abdullah, 2007) dan toleran (Kaneda et al., 1981; Baehaki dan Abdullah, 2007). Namun, melalui penelitian ini diperoleh satu mekanisme ketahanan lagi yang dimiliki oleh kultivar PTB-33, yaitu ketahanan antixenosis (non preference), yang ditunjukkan oleh panjangnya trikoma. Adanya trikoma yang panjang diduga menyebabkan kultivar PTB-33 tidak dipilih oleh wereng cokelat untuk berkembang biak. Kemampuan seperti ini dapat digolongkan dalam mekanisme ketahanan antixenosis (non-preference).

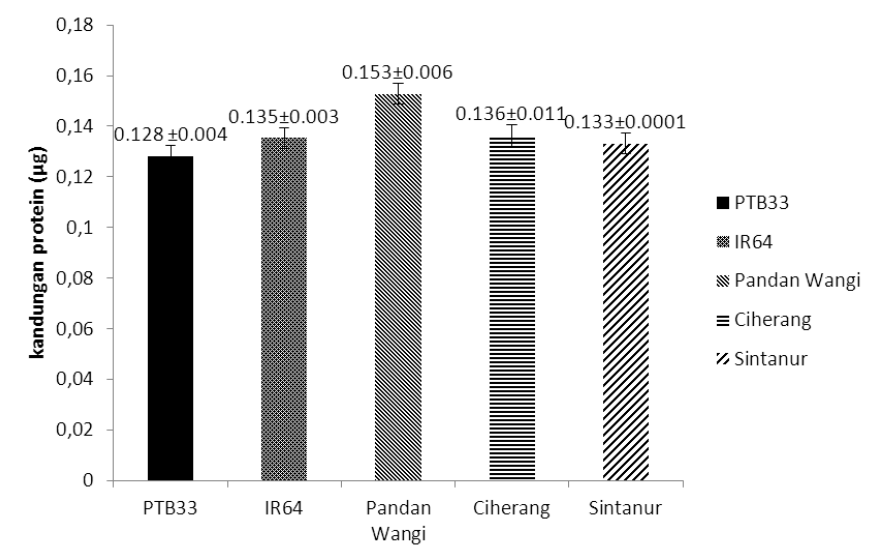

Gambar 1. Kandungan protein pada lima kultivar padi menggunakan metode Bradford. Data menunjukkan nilai mean dengan standard error of means.

Mekanisme ketahanan antibiosis ditunjukkan melalui kandungan protein yang rendah. Rendahnya protein pada kultivar PTB-33 menghalangi pemanfaatan unsur nutrisi oleh wereng cokelat sehingga menghambat perkembangan populasi wereng cokelat. Selain faktor biofisik, faktor biokimia tanaman juga diketahui berfungsi sebagai sistem pertahanan terhadap wereng cokelat (Manuwoto dan Adijuwana, 1991). Pada penelitian ini, salah satu faktor biokimia yang diuji adalah kandungan protein. Hasil yang diperoleh menunjukkan bahwa kandungan protein kultivar PTB-33 lebih rendah yaitu sebanyak 0,128 $\mu \mathrm{g}$, 
dibanding kultivar lainnya (Gambar 1). Mattson (1980) menyatakan bahwa tanaman dengan kandungan protein rendah dapat menyebabkan pertumbuhan serangga tertekan. Berdasarkan pendapat tersebut, maka kandungan protein yang rendah pada kultivar PTB-33 diduga menjadi salah satu faktor pembentuk ketahanan yang tinggi pada kultivar ini terhadap wereng cokelat.

\section{Marker Screening (Skrining Marka)}

Berdasarkan visualisasi yang telah dilakukan pada 8 marka SSRs, diperoleh hasil bahwa 4 marka SSRs tidak menunjukkan adanya polimorphisme. Marka RM7 dan RM313 yang diketahui mendeteksi gen Qbph3 pada kromosom 3 (Sun et al., 2005), tidak menunjukkan adanya polimorphisme (monomorfik) antar pita DNA pada tiap kultivar yang diuji (Gambar 2). Semua kultivar uji memiliki pita DNA dengan ukuran yang sama, yaitu 180bp untuk RM7 dan $111 \mathrm{bp}$ untuk RM313, sesuai dengan PCR product size untuk masing-masing marka tersebut. Hasil ini menunjukkan bahwa pada semua kultivar yang diuji memiliki gen Qbphs sehingga tidak menunjukkan adanya polimorfisme antar kultivar. Hasil yang sama juga diperoleh untuk marka RM8072 yang mendeteksi gen Bph3 pada kromosom 6 (Jairin et al., 2007a) (Gambar 3), dimana tidak terlihat adanya polimorphisme pita DNA antar kultivar. Tidak adanya polimorphisme disebabkan karena semua kultivar uji memiliki pita DNA dengan ukuran 146bp, yang menunjukkan bahwa semua kultivar memiliki gen $B p h 3$.

Polimorphisme secara jelas ditunjukkan oleh marka RM586 dan RM589, yang merupakan marka pendeteksi gen $B p h 3$ dan bph4 pada kromosom $6 \mathrm{~S}$ dan 6 (Jairin et al., 2007a) (Gambar 4), serta marka RM8213 yang mendeteksi dua gen yaitu Qbph4 dan $B p h 17(\mathrm{t})$ pada kromosom 4. (Sun et al., 2005) (Gambar 5). Pada marka RM586 dan RM589, ukuran pita DNA yang ditunjukkan oleh kultivar PTB-33 (271bp) berbeda dengan kultivar lainnya kecuali kultivar IR-64.

Kesamaan ukuran pita DNA ini dapat disebabkan karena kedua kultivar ini memiliki gen $b p h$ yang sama, khususnya gen bph yang terpaut dengan kedua marka yang digunakan. Marka RM586 dan RM589 diketahui terpaut dengan gen Bph3 dan bph4 pada kromosom 6 (Gambar 6). Hasil penelitian yang telah dilakukan menunjukkan bahwa gen $B p h 3$ dan $b p h 4$ telah diteliti dimiliki oleh kultivar PTB-33 (Jairin et al., 2007a; Santhanalakshmi et al., 2010) dan kultivar IR-64 (BB Padi, 2009). Oleh karena itu, penggunaan RM586 dan RM589 nantinya hanya digunakan untuk persilangan kultivar PTB-33 dengan kultivar lainnya, kecuali kultivar IR-64.

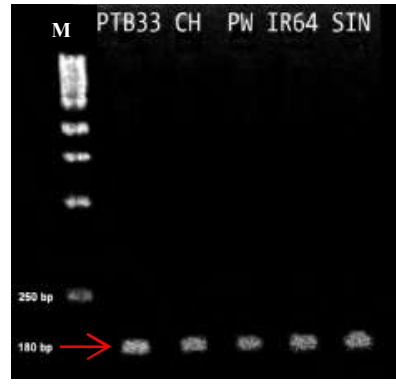

(a)

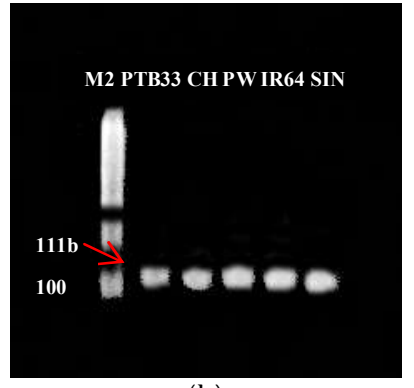

(b)
Gambar 2. Hasil visualisasi (a) RM7 dan (b) RM313 pada lima kultivar padi.

Ket : M1 = DNA Ladder 1000bp; M2 = DNA Ladder 10obp; $\mathrm{CH}=$ Ciherang; $\mathrm{PW}=$ Pandan Wangi; $\mathrm{Sin}=$ Sintanur.

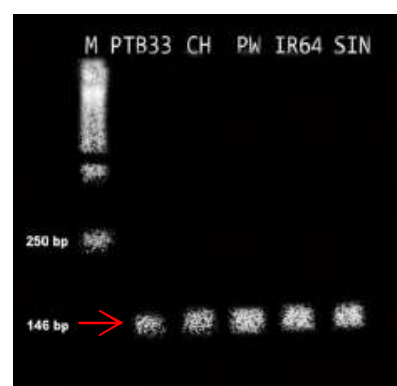

(a)



(b)
Gambar 3. Hasil visualisasi (a) RM8072 dan (b) RM19291 pada lima kultivar padi. Ket : M = DNA Ladder 1000bp; $\mathrm{CH}=$ Ciherang; PW = Pandan Wangi; Sin = Sintanur.

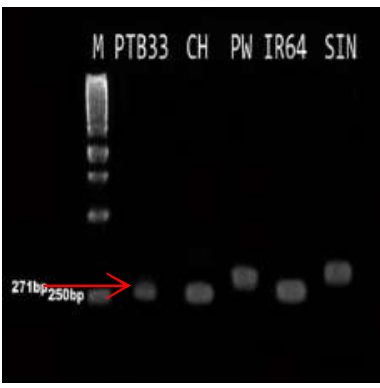

(a)

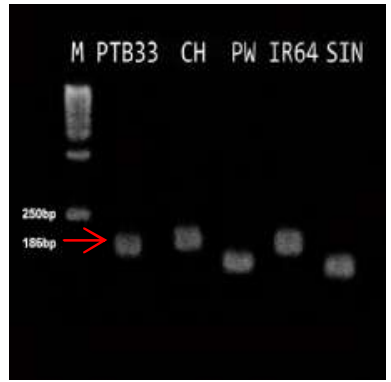

(b)
Gambar 4. Hasil visualisasi (a) RM586 dan (b) RM589 pada lima kultivar padi.

Ket : $\mathrm{M}=$ DNA Ladder 100obp; $\mathrm{CH}=$ Ciherang; PW = Pandan Wangi; Sin = Sintanur.

Hasil visualisasi pada marka RM8213 memperlihatkan adanya polimorphisme, dimana pita DNA kultivar PTB-33 mempunyai ukuran pita DNA (177bp) yang berbeda dengan semua kultivar (Gambar 6). Marka RM8213 diketahui terpaut 
dengan gen Qbph4 dan Bph17(t) (Gambar 6). Hal ini memperlihatkan bahwa terdapat kemungkinan kultivar PTB-33 memiliki gen Qbph4 dan Bph17(t), sehingga menyebabkan adanya polimorphisme dengan kultivar lainnya.

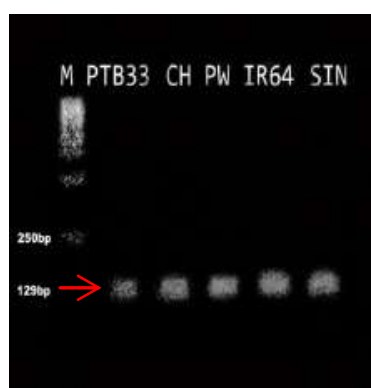

(a)

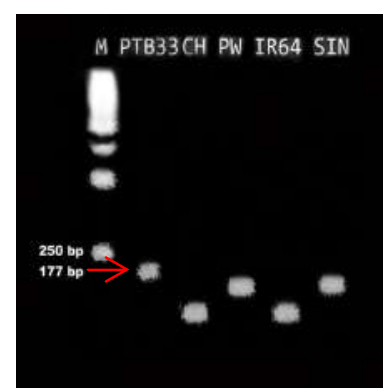

(b)
Gambar 5. Hasil visualisasi (a) RM5953 dan (b) RM8213 pada lima kultivar padi. Ket : $\mathrm{M}=$ DNA Ladder 1000bp; $\mathrm{CH}=$ Ciherang; $\mathrm{PW}=$ Pandan Wangi; Sin $=$ Sintanur.

Hasil yang berbeda diperlihatkan oleh RM5953, dimana tidak terdapat adanya polimorphisme antara kultivar yang diuji, padahal RM5953 juga diketahui terpaut dengan gen yang sama dengan RM8213, yaitu gen $Q b p h 4$ dan Bph17(t) (Gambar 6). Semua kultivar terlihat memiliki pita DNA dengan ukuran 129bp sesuai dengan PCR product size yang diharapkan (Gambar 6). Tidak terdapatnya polmorphisme pada RM5953 diduga karena ukuran fragmen DNA yang terlalu kecil (129bp), sehingga sulit terlihat adanya perbedaan ukuran pita DNA antar kultivar. Oleh karena itu, dibutuhkan optimasi yang lebih baik pada saat elektroforesis, seperti penggunaan Polyacrilamide Gel Electrophoresis (PaGE) yang dapat memisahkan pita DNA lebih baik daripada agarose gel yang digunakan pada penelitian ini.

Adanya kedua gen tersebut, ditambah beberapa gen bph yang telah diketahui sebelumnya pada kultivar PTB-33 seperti Bph3 dan bph4 (Jairin et al., 2007a; Santhanalakshmi et al., 2010), menjadi salah satu alasan ketahanan yang tinggi pada kultivar ini terhadap berbagai biotipe wereng cokelat. Maqbool et al., (2001) menyatakan bahwa adanya beberapa gen ketahanan dalam satu kultivar diketahui dapat membentuk ketahanan yang tinggi pada tanaman. Tipe ketahanan ini dikenal juga sebagai ketahanan horizontal, yaitu kemampuan resistensi terhadap beberapa biotipe sekaligus (multiple resistent). Selanjutnya, berdasarkan hasil visualisasi tersebut, maka RM8213 akan digunakan sebagai marka penseleksi keturunan hasil persilangan antara kultivar PTB-33 dengan kultivar lainnya.

\section{Korelasi Marka dengan Karakter Penting.}

Analisis yang dilakukan selanjutnya yaitu mencari korelasi antara marka yang digunakan serta gen terkait, dengan karakter penting yang diamati. Analisis korelasi difokuskan pada marka yang menunjukkan polimorphisme dengan karakter penting yang berbeda nyata pada kultivar PTB-33 dibandingkan kultivar lainnya.

Hasil analisis Z-mantel pada Tabel 3 memperlihatkan bahwa korelasi yang sangat tinggi ditunjukkan oleh karakter laju fotosintesis dengan marka RM8213 ( $\mathrm{z}=0,94)$ dan karakter panjang trikoma dengan $\mathrm{RM} 8213(\mathrm{z}=0,97)$ dan korelasi yang tinggi antara kandungan protein dengan RM586 ( $\mathrm{z}=$ 0,83). Rohlf (2000) menyatakan bahwa nilai $\mathrm{z}>0,9$ menunjukkan bahwa adanya kecocokan yang sangat baik antara dua matriks yang diuji, kemudian nilai $\mathrm{z}>0,8$ yang berarti baik, sedangkan nilai $\mathrm{z}<0,7$ menunjukkan korelasi yang sangat lemah. Tingginya nilai $\mathrm{z}$ menunjukkan bahwa RM8213 terkait erat dengan pembentukan karakter laju fotosintesis dan panjang trikoma, serta RM586 terkait dengan kandungan protein pada kultivar yang diuji. Oleh karena itu, RM8213 nantinya dapat digunakan sebagai marka penseleksi untuk ketahanan terhadap wereng cokelat berdasarkan karakter laju fotosintesis dan panjang trikoma, dan RM586 sebagai marka penseleksi berdasarkan kandungan protein.

Tabel 3. Hasil analisis Z-Mantel untuk korelasi marka molekuler dengan karakter penting tanaman.

\begin{tabular}{|c|c|c|c|}
\hline \multirow{3}{*}{$\begin{array}{c}\text { Marka } \\
\text { SSR }\end{array}$} & \multicolumn{3}{|c|}{ Karakter Penting } \\
\hline & Laju & Panjang & Kandungan \\
\hline & Fotosintesis & Trikoma & Protein \\
\hline RM586 & 0,39 & 0,18 & 0,83 \\
\hline RM589 & 0,62 & 0,28 & 0,16 \\
\hline RM8213 & 0,94 & 0,97 & 0,52 \\
\hline
\end{tabular}

Ket : angka pada tabel menunjukkan nilai $\mathrm{z}$ berdasarkan analisis Z-Mantel.

Gen Bph yang terpaut dengan kedua marka tersebut (RM586 dan RM8213) yaitu gen Bph3, bph4, Qbph4 dan Bph17(t) (Gambar 6). Sebelumnya, Horgan (2009) telah melakukan studi review terhadap beberapa gen $b p h$ dan karakter yang terkait, antara lain gen $B p h 1$ dan $B p h 3$ dengan lapisan lilin di permukaan daun, kandungan schaftosides yang lebih tinggi, serta gen Bph3 dan bph4 dengan kemampuan pertahanan tanaman saat 
diserang. Namun, fungsi dari gen $b p h$ lainnya (Bph5 hingga 21) belum diketahui. Melalui penelitian ini, diperoleh beberapa informasi tambahan mengenai gen $b p h$, khususnya gen $B p h 3, b p h 4$, Qbph4 dan $B p h 17(\mathrm{t})$ serta keterkaitannya dengan karakter penting terkait ketahanan tanaman. Berdasarkan nilai $\mathrm{z}$ yang ditunjukkan oleh Tabel 3, terlihat bahwa gen $Q b p h 4$ dan $B p h 17(\mathrm{t})$ mempunyai korelasi yang sangat tinggi dengan karakter laju fotosintesis $(94 \%)$ dan panjang trikoma (97\%), sedangkan gen gen Bph3 dan bph4 berkorelasi tinggi dengan kandungan protein $(83 \%)$ pada kultivar yang diuji.

Informasi keeratan hubungan marka dengan karakter-karakter penting ini nantinya dapat digunakan sebagai alat untuk mempercepat seleksi pada populasi keturunan yang sedang bersegregasi. Hal ini dikarenakan seleksi berdasarkan genotipik dapat dilakukan pada usia dini dibandingkan dengan seleksi fenotipik (Jena and Mackill, 2008; Collard and Mackill, 2010; Ashkani et al., 2012). Beberapa penelitian untuk aplikasi MAS pada padi juga menunjukkan bahwa gen target bisa diidentifikasi lebih baik pada populasi bersegregasi pada berbagai fase pertumbuhan tanaman dengan penggunaan marka-marka DNA yang terkait erat (Huang et al, 1997; Ashkani et al., 2012). Hanya saja belum diketahui seberapa besar pengaruh gen-gen $b p h$ tersebut terhadap kedua karakter terkait, karena adanya gen-gen lain yang diketahui berperan terhadap laju fotosintesis dan panjang trikoma. Laju fotosintesis diketahui dikendalikan oleh banyak gen (Hatchel, 1997) sedangkan karakter trikoma pada padi antara lain dikendalikan oleh gen Glabrous Rice 1 (GLR1) (Li et al., 2012). Oleh karena itu, dibutuhkan penelitian lebih lanjut di tingkat molekuler dan fenotipik pada galur-galur keturunan untuk mengetahui fungsi masing-masing gen $b p h$ dengan karakter penting terkait ketahanan tanaman.

\section{Kesimpulan}

1. Kultivar tahan wereng cokelat, PTB-33, memiliki laju fotosintesis yang lebih tinggi (toleran), trikoma yang lebih panjang (antixenosis), dan kandungan protein yang lebih rendah (antibiosis) dibandingkan kultivar lainnya.

2. Marka RM8213 menunjukkan pola pita (band) DNA yang berbeda (polimorphisme) untuk gen Bph terkait, pada kultivar PTB-33 dibandingkan kultivar lainnya, sedangkan marka RM586 dan RM589 juga menunjukkan polimorphisme pada kultivar PTB-33 dengan kultivar lainnya kecuali dengan kultivar IR-64.

3. Gen Qbph4 dan Bph17(t) mempunyai korelasi yang sangat tinggi dengan karakter laju fotosintesis dan panjang trikoma, dan gen $B p h 3$ dan $b p h 4$ berkorelasi tinggi dengan kandungan protein.

\section{Ucapan Terima Kasih}

Penulis mengucapkan terima kasih kepada Santika Sari yang telah membantu dalam eksperimen dan kepada Dikti yang telah membiayai sebagian riset ini melalui skema Hibah Strategis Nasional.

\section{Daftar Pustaka}

Ashkani, S., Rafii, M.Y., Rusli, I., Sariah, M., Abdullah, Siti N.A., Rahim, H.A, Latif, M.A. 2012. SSRs for marker-assisted selection for blast resistance in rice (Oryza sativa L.). Plant Mol Biol Rep 30:79-86.

Baehaki, S.E., dan Abdullah, B. 2007. Evaluasi karakter ketahanan galur padi terhadap wereng coklat biotipe 3 melalui uji penapisan dan uji peningkatan populasi. Apresiasi Hasil Peneliatian Padi : 367-382.

Brar, D.S., Virk, P.S., Jena, K.K., and Khush, G.S. 2009. Breeding for resistance to planthoppers in rice. Planthoppers: new threats to the sustainability of intensive rice production systems in Asia. Los Baños (Philippines): International Rice Research Institute. pp 401-428.

Brumlop, S. and Finckh, M.R. 2011. Applications and potentials of marker assisted selection (MAS) in plant breeding. Final report of the $\mathrm{F}+\mathrm{E}$ project "Applications and Potentials of Smart Breeding" (FKZ 350889 0020) on behalf of the Federal Agency for Nature Conservation.

Chandramani, P., Rajendran, R., Sivasubramanian, P., and Muthiah, C. 2009. Impact of biophysical factors as influenced by organic sources of nutrients on major pests of rice. Journal of Biopesticides, 2(1): 01-05.

Chen, Y.H. 2009. Variation in planthopper-rice interactions: possible interaction among three species?. Pp 315-339. in Planthoppers: New threats to the sustainability of intensive rice production systems in Asia. Heong KL and Hardy B (Eds). Los Bannos Philippines. International Rice Research Institute. 460p.

Collard, B.C.Y. and Mackill, D.J. 2010. Marker-assisted selection: an approach for precision of plant breeding in the twenty-first century. Phil Trans. R. Soc. B 363:557-572.

Hachtel, W. 1997. DNA and gene expression in photosynthetic plastids (chloroplasts). Hand Book of Photosinthesis. New York: Marcel Dekker, p331-348.

Huang, N., Angeles, E.R., Domingo, J., Magpantay, G., Singh, S., Zhang, Q., Kumaravadivel, N., Bennett, J., and Khush, G.S. 1997. Pyramiding of bacterial resistance genes in rice: marker-aided selection using RFLP and PCR. Theor Appl Genet 95:313-320

Horgan, F. 2009. Mechanisms of resistance: a major gap in understanding planthopper-rice interactions. Pp 281-302 in Planthoppers: New threats to the 
sustainability of intensive rice production systems in Asia. Heong KL and Hardy B (Eds). Los Bannos Philippines. International Rice Research Institute.

Indiati, S.W. 2004. Penyaringan dan mekanisme ketahanan kacang hijau MLG-176 terhadap hama thrips. Jurnal Litbang Pertanian, 23 (3).

IRRI. 2002. Standar Evaluation System for Rice (SES). International Rice Research Institute, Philippines. p56.

Jairin, J., Teangdeerith, S., Leelagud, P., Phengrat, K., Vanavhicit, A., and Toojinda, T. 2007. Detection of brown planthopper resistance genes from different rice mapping populations in the same genomic location. Science Asia 33:347-352.

Jairin, J., Phengrat, K., Teangdeerith, S., Vanavichit, A., and Toojinda, T. 2007. Mapping of a broad-spectrum brown planthopper resistance gene, $B p h 3$, on rice chromosome 6. Mol Breeding 19:35-44.

Jena, K.K., Jeung, J.U., Lee, J.H., Choi, H.C., and Brar, D.S. 2006. High-resolution mapping of a new brown planthopper $(\mathrm{BPH})$ resistance gene, $B p h 18(t)$, and marker-assisted selection for $\mathrm{BPH}$ resistance in rice (Oryza sativa L.). Theor. Appl. Genet. 112:288-297.

Jena, K.K. and Mackill, D.J. 2008. Molecular markers and their use in marker-assisted selection in rice. Crop Sci. 48:1266-1276.

Jena, K.K., Suh, J.P., Lee, J.H., Yang, S.J., Pamplona, A., and Kim, Y.G. 2009. Development of brown planthopper $(\mathrm{BPH})$ resistant breeding lines using marker-assisted selection in rice. Crop Sci. 48 (4):1266-1276

Johnson, M.W., Welter, S.C., Toscano, N.C., Ting, I.P., Trumble, J.T. 1983. Reduction of tomato leaflet photosynthesis rates by mining activity of Liriomyza sativae. J Econ Entomol 76: 1061-1063.

Junengsih, Danar Dono dan Carsono, N. 2012. Ketahanan padi transgenick DB-1 terhadap wereng coklat biotipe Sumatera Utara. Hasil penelitian. Tidak dipublikasikan.

Kaneda, C., Ito, K., and Ikeda, R. 1981. Screening of rice cultivars for resistance to brown planthopper, Nilaparvata lugens Stal., by three genotypes. Japan. J. Breed., 31(2) : 141-151.

Kumari, S., Sheba, J.M., Marappan, M., Ponnuswamy, S., Seetharaman, S., Pothi, N., Subbarayalu, M., Muthurajan, R., and Natesan, S. 2010. Screening of IR50 3 Rathu Heenati F7 RILs and identification of SSR markers linked to brown planthopper (Nilaparvata lugens Stal) Resistance in Rice (Oryza sativa L.). Mol Biotechnol 46 : 63-71.

Li, J.B., Xia, M.Y., Qi, H.X., He, G.C., Wan, B.L., and Zha, Z.P. 2006. Marker-assisted selection for brown planthopper (Nilaparvata lugens Stål) resistance genes Bph14 and Bph15 in rice. Sci. Agric. Sin. 39:21322137.
Li, J., Yuan, Y., Lu, Z., Yang, L., Gao, R., Lu, J., Li, J., and Xiong, G. 2012. Glabrous Rice 1, encoding a homeodomain protein, regulates trichome development in rice. Springer Open. Melalui http://www.thericejournal.com/content/5/1/32. $[01 / 12 / 12]$

Manuwoto, S., dan Adijuwana, H. 1991. Mekanisme dan faktor kimia yang mendasari resistensi beberapa varietas padi terhadap wereng batang coklat Nilaparvata lugens Stal (Homoptera : Delphacidae). J.II.Pertanian Indonesia Vol. 1(1).

Maqbool, S.B., Riazuddin, S., Loc, N.T., Gatehouse, A.M.R., Gatehouse, J.A., and Christou, P. 2001. Expression of multiple insecticidal genes confers broad resistance against a range of different rice pests. Mol. Breed. 7:85-93.

Mattson, W.J. 1980. Herbivory in relation to plant nitrogen content. Annu Rev Ecol Syst 11:119-161.

Nagadhara, D., Rameshi, S., Pasalu, I.C., Rao, Y.K., Sarma, N.P., Reddy, V.D., and Rao, K.V. 2004. Transgenic rice plants expressing snowdrop lectin genes (GNA) exhibit high-level resistance to the whitebacked planthopper (Sogatella furcifera). Theor Appl Genet 109:1399-1405.

Nugaliyadde, L., Des Abeysiriwardena, D.S., Samanmalee, L.G.A., Pathirana, R., and Wilkins, R.M. 2004. Inheritance of resistance in rice to brown planthopper: its implications on rice varietal improvement in Sri Lanka. Melalui http://www.goviya.lk/agri_learning/Paddy/Paddy_ Research/Paddy_pdf/P3.pdf. [26/11/10].

Santhanalakshmi, S., Saikumar, S. and Rao, S. 2010. Mapping genetic lokus linked to brown planthopper linked to rice Oryza sativa L. Intl. J. Plant Breeding and Genetics 4: 13-22.

Sharma, P.N., Torii, A., Takumi, S., Mori, N., dan Nakamura, C. 2004. Marker-assisted pyramiding of brown planthopper (Nilaparvata lugens $\mathrm{Sta}^{\circ} \mathrm{l}$ ) resistance genes $B p h 1$ and $B p h 2$ on rice chromosome 12. Hereditas 140: 61-69.

Sun, L., Su, C., Wang, C., Zhai, H., and Wan, J. 2005. Mapping of a major resistance gene to the brown planthopper in the rice cultivar Rathu Heenati. Breeding Science 55 : 391-396.

Sun, L.H., Wang, C.M., Su, C.C., Liu, Y.Q., Zhai, H.Q., and Wan, J.M. 2006. Mapping and marker-assisted selection of a brown planthopper resistance gene bph2 in rice (Oryza sativa L.). Acta Genetica Sinica 33 (8) : 717-723.

Wang, Y., Wang, X., Yuan, H., Chen, R., Zhu, L., He, R., and He, G. 2008. Responses of two contrasting genotypes of rice to brown planthopper. The American Phytopathological Society : Molecular Plant-Microbe Interactions. 21(1) : 122-132. 